\title{
ISA 701: KEY AUDIT MATTERS - AN EXPLORATION OF THE RATIONALE AND POSSIBLE UNINTENDED CONSEPUENCES IN A SOUTH AFRICAN
}

\author{
Milton Segal* \\ University of the Witwatersrand
}

Received: November 2016

Accepted: January 2017

\begin{abstract}
The New International Standard of Auditing (ISA) statement number 701 titled key audit matters (KAM) has been reported as one of the most significant changes to the audit profession and the manner in which audit reports are to be delivered. Effective from 15 December 2016, auditors for Johannesburg Stock Exchange (JSE) - listed companies will need to disclose key and significant transactions that occurred on the audit, even in the event of an unmodified audit opinion. The legislators describe this as increasing transparency and accountability to enhance the fairness of reporting and to assist the stakeholders with understanding the audited annual financial statements. This paper uses a detailed content analysis of prior academic and professional audit literature to explore possible unintended consequences, uncertainties and risks of the KAM. These include disclosure of potential confidential information and potentially increased auditor's liability. These findings give the paper scope to make a meaningful contribution by critically assessing the proposed introduction of the KAM with the aim of informing auditing legislative development and future quantitative studies on the introduction of the KAM in South Africa.
\end{abstract}

Keywords

Key audit matters, transparency, auditor liability, unintended consequences, relevance, disclosure

*Mr M Segal is a senior lecturer in the School of Accounting at the University of the Witwatersrand, Johannesburg, South Africa. [milton.segal@wits.ac.za] 


\section{INTRODUCTION}

South Africa has long been lauded as having the highest rating when it comes to accounting practice, accounting standards and audit reporting (Maroun \& Gowar, 2013; Business Day, 2014). South Africa ranks first in the world in respect of the strength of auditing and reporting standards (Bowes, Lundy \& Pennington, 2004; World Economic Forum, 2014). Closely linked to this is a significant emphasis on the audits that are performed. The majority of prospective Chartered Accountants who serve their articles/traineeship at a South African Institute of Accountants (SAICA)-accredited training institution serve at least three years in the audit environment (Kretzschmar, Prinsloo, Prozesky, Rossouw, Korien, Siebrits \& Woermann, 2013). During this period, candidates are exposed to a wide range of transactions in many sectors and the candidate gains an understanding of whether these transactions comply with the appropriate accounting and auditing standards or not. Furthermore, if not, the Chartered Accountant (SA) is trained as to what the potential effect, if any, this non-compliance may have on the audit report, (Puttick, Van Esch \& Kana, 2008). This suggests that if a modification is required, the opinion would be modified and the reason for the modification would be disclosed.

The audit culminates in the audit opinion. The opinion provides reasonable assurance as to whether the Annual Financial Statements (AFS) fairly present the results of operations and the financial position of the entity at the financial year-end (International Audit and Assurance Standards Board (IAASB), 2014b). In a sense, at the discretion of the audit partner and firm, a type of yes/no or pass/fail opinion is given on the organisation (Francis, 2004; Carcello, 2012). Although it does not certify one hundred percent factual correctness, a clean audit report concludes that fair presentation with no material misstatement has been made (Hayes, Wallage \& Gortemaker, 2014).

However, as in the infamous case of Enron, one of the most significant corporate scandals of the modern era, Arthur Anderson had reported an unmodified audit opinion on the AFS, despite the fact that the corporation had large off balance sheet financed debt and numerous dubious 'creative accounting' transactions 'hidden' in its AFS (Porter \& Gowthorpe, 2004; Cordos \& Fulop, 2015). This in turn led to its downfall, unmodified audit report and all.

In the case where a modified audit opinion is given, additional information with regard to the opinion is provided to the users (IAASB, 2014c; Grosu, Robu \& Istrate, 2015). An important aspect of the current standard is that where a clean or unmodified opinion is given, no further corroboration from the auditor is required in terms of the opinion disclosed (Gold, Gronewold \& Pott, 2012).

It is expected then that the user would rely on his/her own professional judgement and the professional scepticism (ISA 200), due care and quality control process of the professional firm in reaching the unmodified audit opinion in terms of the International Standard on Quality Control (ISPC 1).

Reliance is then placed on the audit report by the relevant users of the AFS. Users are not limited to the shareholders but also include a wide range of stakeholders such as suppliers, customers, employees, regulators such as the South African Revenue Service (SARS) and, in the case of a public entity, the citizens of the country (Kretzschmar et al., 2013).

The question can consequently be raised about why the additional disclosure with regard to the audit opinion was deemed necessary. A possible solution could be that there is perhaps some doubt over the opinions expressed or the ability of the auditor to express this opinion. In addition, 
users may seek additional guidance and clarification, which is currently not being disclosed adequately (Cordos \& Fulop, 2015).

This research continues with this line of thought by exploring the possible unintended consequences of the proposed introduction of key audit matters (KAM). A detailed content analysis of the existing body of literature on the introduction of the KAM is carried out to identify key arguments and counter-arguments in favour of its introduction. The absence of direct prior research on the KAM in South Africa means that this research is interpretive.

This article does not fully examine the potential benefits of the new legislation, and does not provide a robust summary thereof, nor does it act as a comparative study between the possible advantages and disadvantages of this particular new audit standard. Furthermore, it does not provide a quantitative assessment of the costs and benefits of the KAM introduction in South Africa but rather seeks to add to the existing debate on the implementation.

While this may be construed as a threat to validity and reliability in a positivist sense (Creswell, 2009), the normative and qualitative style sheds light on what is and should be happening when it comes to South Africa's audit reporting structure, thus making an important contribution to audit reporting transparency and accountability (see Ahrens, Becker, Burns, Chapman, Granlund, Habersam, Hansen, Khalifa, Malmi, \& Mennicken, 2008; Humphrey, Kausar, Loft, \& Woods, 2011). At the same time, the exploratory style provides a basis for subsequent research, which could rely on quantitative methods.

The remainder of this article is organised as follows: section 2 provides an in-depth look into the theoretical framework, that of unintended consequences. Section 3 outlines the audit opinion, describing the audit framework in the context of the audit opinion and the link this has to the KAM; it also includes a discussion on the going concern opinion and the connection to the KAM, as well as a discussion on the proposed implementation initially on listed entities. Section 4 discusses certain possible consequences of the introduction of the KAM. Section 5 concludes and identifies areas for future research.

\section{THEORETICAL FRAMEWORK: UNINTENDED CONSEPUENCES OF REGULATORY DEVELOPMENTS}

In examining corporate governance literature various examples of regulatory developments inducing unintended consequences have been identified. The Sarbanes Oxley Act (2002) (SOX), which was implemented in order to enhance confidence in capital markets and improve the control environment in corporations, has prompted studies examining the unintended consequences of its implementation (Vakkur, Mcafee, \& Kipperman, 2010). SOX has resulted in an inflexible environment focusing on rules rather than conceptual compliance, and has inadvertently resulted in a decrease in the value of firms (Maroun, 2012).

In examining a financial reporting environment, the introduction of monitoring bodies that are aimed at ensuring certain quality reporting levels does not always result in an improved quality of reporting (Maroun, 2015a).

The inflexible rules-based approach followed by SOX, coupled with sanctions for non-compliance, has led to a decline in the value of firms. Similarly, the introduction of quality inspections by the Public Company Accounting Oversight Board (PCAOB) aimed at improving the quality of external audit $(P C A O B, 2007)$ has had unintended consequences for the quality of corporate reporting. 
Delays in completing the audit of financial statements has resulted in the release of preliminary results by companies before the completion of audit fieldwork, leading to a decline in the reliability of preliminary announcements (Bronson et al., 2011). "Each case highlights how reforms, 'not well informed by and well-grounded' in 'professional practice and the wide array of factors' influencing and shaping regulatory domains 'run the risk of producing unintended and potentially dysfunctional consequences'” (Segal \& Maroun, 2014).

Although in a different context, the use of an example using a tax principle helps to unpack this potential pitfall - that is, an unintended and often unplanned consequence. In a taxation context, laws and regulations implemented by authorities to eliminate anti-avoidance transfer pricing schemes have often been unsuccessful and have instead added increased complexity and costs to the tax system both locally and internationally (Stiglingh, 2011). The unintended result of these increased taxation compliance implementations is an increased administrative responsibility on the taxpayer, which is often a smaller business without the sufficient resources and capability to manage the increased financial expenditure (Maroun, 2015a).

Reflecting on auditing-specific areas, a further example is that the quality reviews by the Public Company Accounting Oversight Board (PCAOB), which are designed to improve the reliability and standards of external audits, have resulted in unintended consequences for the quality of audit reporting (Segal \& Maroun, 2014). This has occurred through the increased time taken to complete the audit of financial statements and, as a result, preliminary results have been released by companies prior to the actual audit work being completed, and this has resulted in a decrease in the dependability of these preliminary results (Segal \& Maroun, 2014). Humphrey et al. (2011) also noted that even though there are increased regulations continually being implemented in the audit profession, there is minimal actual effect on the quality of the audit being performed (Power, 1994; Parker, Guthrie, Milne \& Humphrey, 2008). The increased attempts at regulating the non-audit services performed, partner rotation and audit reporting requirements have not always resulted in the desired effects that were expected (Maroun, 2015a).

The situations highlighted above reflect how legislation and changes which have not been well grounded in professional practice 'run the risk of producing unintended and potentially dysfunctional consequences' (Humphrey et al., 2011). The aim of this literature review is not to provide a complete analysis of any potential problematic or negative aspects of the introduction of new auditing legislation. What is important to appreciate is that rarely are proposed regulatory developments free from unintended consequences (Segal \& Maroun, 2014).

\section{AUDIT OPINION AND KEY AUDIT MATTERS (KAM)}

The objective of an audit of financial statements is to enable the auditor to express an opinion on whether the financial statements were prepared, in all material respects, in accordance with an applicable financial reporting framework (IAASB, 2009). It can be concluded then that the audit of financial statements is an assurance engagement, as defined in the International Framework for Assurance Engagements.

The audit firm carries out the engagement according to the standards to which the International Standards of Auditing (ISAs) apply and also in accordance with the audit firm's own internal policies (Maroun \& Atkins, 2014). Predominantly, audit firms use a risk-based approach to auditing. By doing this, during the planning phase of the audit, the auditor identifies the main areas of risk ( $a$ ) that the entity faces and (b) how these risks may affect the annual financial 
statements and, by default, the audit (IAASB, 2009; IAASB, 2014d). ISA 200 divides the risks into three main risk categories, namely 'Inherent Risk', 'Control Risk' and 'Detection Risk'. Discussions of these three main risk categories are highlighted below in order to further corroborate the already stringent audit quality process and areas that need to be addressed by auditors in South Africa. It is suggested that each of these risks is a key risk and, by inference, a key audit matter.

\section{Inherent Risk}

ISA 200 pl3 defines 'inherent risk' as the susceptibility of an assertion about a class of transaction, account balance or disclosure to a misstatement that could be material, either individually or when aggregated with other misstatements, before consideration of any related controls. This represents the 'inherent' or environmental risks that the client faces. These risks include environmental risks such as geographic factors, environmental risks such as pollution, weather, currency fluctuations as a result of being exposed to foreign currency, and other such risks (Maletta, 1993). While the auditor is required to be aware of these risks, there is no procedure that the auditor can put in place to mitigate the risk. That in part is done by the entity's own internal control mechanisms and its management of 'control risk' (Hogan \& Wilkins, 2008).

\section{Control Risk}

'Control risk' represents the auditor's assessment of the likelihood that a material misstatement in relation to a financial statement assertion will not be detected or corrected on a timely basis by the client's internal control system (Mackenzie et al., 2013).

All audits require the auditor to test its client's internal control processes (ISA $315 \mathrm{R}$ ). The results of these tests will determine to what extent (if any) the audit firm can rely on the fact that its client's internal control mechanism would have prevented, detected and corrected any material misstatement (Mackenzie et al., 2013). In addition, no matter the extent and magnitude of a client's internal control systems, the auditor is required in terms of ISA 315 R to test and document its client's internal control system irrespective of whether the auditor will place any reliance on the system, or not (IAASB, 2014d).

It is submitted, then, that the auditor is required to gain a thorough understanding of its client's internal controls, management integrity and overall governance. It is concluded that the abovementioned testing plays a significant role in determining the overall opinion expressed by the auditor (Mackenzie et al., 2013). In the current audit report (ISA 700), no detail is required to be disclosed as to the nature, timing and extent of the procedures followed by the auditor.

\section{Detection Risk}

'Detection risk' is defined by ISA $315 \mathrm{R}$ as the risk that the auditor's substantive testing will not detect a material misstatement (IAASB, 2014d). This risk is borne by the auditor. As with 'control risk', the auditor would need to balance this risk with how much reliance it can place on the client's controls. This would entail that the higher the control risk, the less reliance the auditor can place on the client's controls and, as a result, the more substantive work would need to be performed by the auditor to reduce the detection risk to an acceptable level (Johnstone, 2000).

In order to effectively lower the 'detection risk', the auditor implements a variety of different quality safeguards as required by ISPC 1 . According to ISPC 1 , audit engagement teams require the necessary and appropriate skills and resources in order to conduct the engagement. Quality control mechanisms include the allocation of an engagement partner who has the appropriate 
time and skills necessary to lead the engagement (Maroun \& Atkins, 2014). Each client has its own unique risk and quality control mechanisms that must address the risk-specific nature of the client, specifically the skill-set and appropriate supervision, monitoring and review of the less experienced engagement team by the more experienced team (Maroun \& Atkins, 2014).

Because by nature it has to express an opinion, an audit often requires significant professional judgement. Because of this, quality control mechanisms are put in place by audit firms that require a mentoring and monitoring process by more experienced staff assigned to the audit (Maroun \& Atkins, 2014). ISPC 1 requires consultation on difficult and contentious issues which should be appropriately documented and which will result in a lowering of 'detection risk' (Maroun \& Atkins, 2014). Quality control is not static, and audit firms should be continually reassessing their design operation and the effectiveness of their quality control systems (ISPC 1 ). This should specifically be carried out by senior and experienced partners and should be aimed at continual improvement and corrective action if required (Maroun \& Atkins, 2014).

In addition, it should be noted that the firms themselves are subject to a review process by the Independent Regulator Board for Auditors (IRBA) and as a result have their own internal quality control processes such as partner rotation and peer review of files to further supplement the stringent quality control mechanisms and safeguards.

This KAM report seeks to require disclosure by the auditor of these quality control safeguards and implementations to be disclosed (ISA 701: Communicating Key Audit Matters in the Independent Auditors Report). Cordos and Fulop (2015) conclude that, by inference, there is surely a lack of investor confidence in the audit opinions or, perhaps, it is a case in which the users of the financial statements who are reliant on the audit opinion seek additional comfort in that as expressed by the auditors.

Audit quality is of vital importance to the economy (Cordos \& Fulop, 2015). Audit quality is a fundamental pillar of the audit market and auditing, and the audit itself has no value if the public has no confidence in the assurances given (Maijoor \& Vanstraelen, 2012: Cordos \& Fulop, 2015). Consequently, the opinion reached and mechanisms used by the auditor to reach the opinion are significant and 'key' in nature.

\subsection{Key audit matters linked to the audit opinion}

ISA 701:8 defines key audit matters as 'Those matters that, in the auditor's professional judgment, were of most significance in the audit of the financial statements of the current period' (IAASB, 2015). It also states that key audit matters are selected from matters communicated with those charged with governance.

ISA 701:9 gives examples of such matters as matters 'requiring significant auditor attention during the audit' (IAASB, 2015). These include areas of significant risk, as well as areas where professional judgement must be used.

The word 'key' is defined by the 0xford English Dictionary (Simpson \& Weiner, 1989) as 'of crucial importance': applying this to a key audit matter, this could be interpreted as an audit matter of crucial importance.

The main changes in audit reporting are aimed at reducing the information gap. The International Auditing and Assurance Standards Board (IAASB) has defined this gap as the difference between the information user's desire and what is available to him/her through the entity's disclosures and the auditor's report. It appears then that users and/or investors in general may not have the 
appropriate expertise to analyse the annual financial statements and are thus looking for a summarised view from the auditor to give users more confidence.

For example, in the invitation to comment (Humphrey, Samsonova, \& Siddiqui, 2013), Arnold Schilder, the IAASB Chairman, (Schilder, 2011) states in his IAASB chairman's statement

What does today's auditor's report on financial statements deliver? It is generally a short, standardized report that describes the financial statements subject to audit, the audit itself and the respective responsibilities of management and the auditor. The global financial crisis also has spurred users, in particular institutional investors and financial analysts, to want to know more about individual audits and to gain further insights into the audited entity and its financial statements. And while the auditor's opinion is valued, many perceive that the auditor's report could be more informative. Change, therefore, is essential.

The diagram below has been extracted from the Accountancy SA journal to diagrammatically contextualise key audit matters. It represents the three main areas that ISA 701 requires the auditor to disclose as part of the KAM.

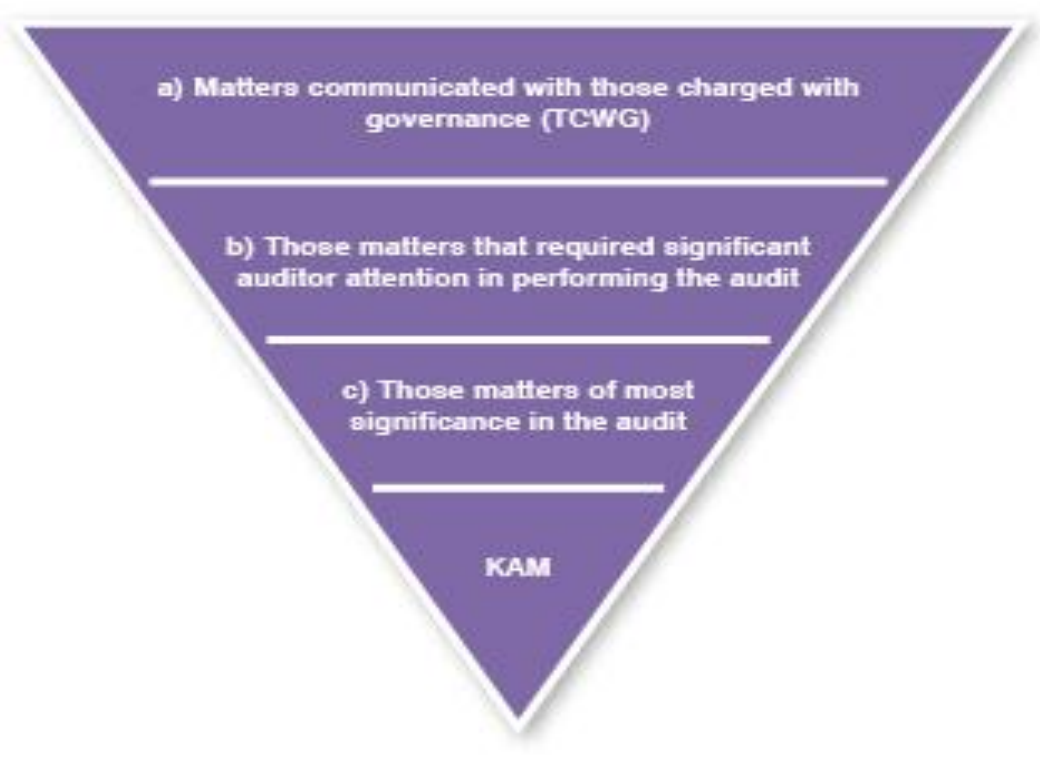

Source: Accountancy SA (April 2015).

\subsection{Going concern}

In providing the audit opinion, the auditor also provides assurance relating to the going concern of the entity. Going concern is one of the fundamental pillars of corporate reporting. IAS I requires the presentation of an entity's financial statements, based on the assumption that the entity will be a going concern, i.e. able to settle its liabilities and realise its assets through the ordinary course of business activities (Defond, Raghunandan, \& Subramanyam, 2002; IASB, 2014).

One of the more serious cases of a corporate entering bankruptcy was that of Parmalat in 2003. Parmalat was involved in a scandal amounting to around 8 million euros (Demaki, 201; Cordos \& 
Fulop, 2015). This was despite going concern assurances issued by the auditor by way of an unmodified audit report (Melis, 2005). To this extent, questions were posed about the role of the auditor, as the audit opinion issued for that period did not suggest there was a material concern with regard to the going concern of the entity in question (Melis \& Melis, 2004).

In order for the auditor to express an opinion on an entity's ability to continue as a going concern, the auditor is required to comply with ISA 570 (IAASB, 2014a). This standard sets out numerous substantive tests (Blay, Sneathen \& Kizirian, 2007) required by the auditor, such as discussions with those charged with governance, a review of management's future cash flow forecasts and budgets. Furthermore, the auditor is also required to take cognisance of market conditions, business conditions and the related environments and other relevant risks in order to reach an opinion of an entity's going concern (IAASB, 2014a). It can be concluded that the going concern opinion expressed by auditors is one of the most fundamental opinions made in the auditor's report (Asare, 1992) and has a high impact on investor responses judged by the market reactions from a change in going concern review (Chen \& Church, 1996).

In addition, ISA 700 requires the auditor to be confident about an entity's going concern in order to reach an unmodified or unqualified opinion (IAASB, 2014b). In the event that an entity has prepared its financial statements on the wind-up basis, the auditor must highlight this to the users by way of an emphasis of matter paragraph (IAASB, 2014a). The international literature supports the significance of a going concern review, and suggests that the issuance of a going concern review by the auditor would potentially have an adverse effect on both the audit firm as well as the audit client (Antle \& Nalebuff, 1991; Carcello \& Neal, 2000). The adverse effect from the client's perspective would be potential adverse market reactions to the going concern review. For the auditors, the potential negatives are fee pressure, a breakdown in the relationship between the client and the auditor and a higher chance of the client switching audit firms (Carcello \& Neal, 2000).

It was noted during a presentation hosted by the South African Institute of Chartered Accountants on 19 May 2015 in Sandton that a likely area which would be included in the KAM report would be justification about the entity's going concern review. In this presentation, it was suggested by Dan Montgomery, a previous IAASB chairperson, that 'the auditor is required to challenge the adequacy of going concern calculations and disclosure by management'. The suggestion was more of an interrogation of the calculations and assumptions made by management.

It is concluded then that the going concern opinion in the audit report would always be a key audit matter. Using the guidelines in the standard, the auditor would have to expand and disclose on the work conducted during the audit which allowed the auditor to reach this conclusion. This going concern disclosure could also pose legal risks to the auditor, as discussed in chapter 3.2.

\section{KAM in South Africa:}

In the South African context, the roll-out of auditors having to comply with the new audit reporting will be for all entities listed on the Johannesburg Stock Exchange (JSE) whose year-end reporting period is on or after 15 December 2016 (Nkonki, 2015). The decision initially to roll this out to listed companies is an interesting one.

On the one hand, it can be argued that the most prominent users of audited financial statements are investors of listed entities. On the other hand, this may be a risky rollout strategy due to the materiality of the listed entities' financials and the wide range of users who would gain access to this report. 
All listed entity shareholders are entitled to receive a set of the audited financial statements and use these for speculative investment purposes (Cooke, 1992). Since the audited results of these entities are in the public domain, on the one hand, it makes sense to roll out the changes in this context, as this would appear likely to have the most material impact on the users of these annual financial statements, if at all (Nkonki, 2015).

This, in turn could, and, in all probability would, expose the audit opinion and the justification of the opinion made by the auditors into the public domain. This would release the new KAM standard into an environment where it could be accurately and quickly ascertained what the market reaction to this enhanced disclosure will be, if any (Nkonki, 2015).

This, in turn, may then influence the decision of the IAASB as to whether this enhanced disclosure should be made mandatory to all those entities requiring or producing an audited set of accounts. In summary, it may be a logical methodology to require the approximately 400 listed companies which produce audited accounts to have their audit opinion's enhanced disclosure accessible to all its users (Bédard, Gonthier-Besacier \& Schatt, 2014).

However, empirical research carried out in Europe (section 4) points to the fact that the market did not react materially or significantly at all to the additional reporting (Bédard et al., 2014). Their findings suggested that the audit report was merely a symbolic gesture (see chapter 4.4), as the market does not wait for the release of audited accounts before it reacts. The market tends to price itself around speculation and expectation. Should a similar pattern present itself in South Africa, is this perhaps a case then for diminishing the relevance of the new ISA 701 (IAASB, 2015)? The lack of relevance may increase the risk of the exercise being reduced to a compliance-based, tick box, boiler plate type approach as evidenced in France from 2003 to 2007 (Bédard et al., 2014).

\section{UNINTENDED CONSEPUENCES OF THE PROPOSED INTRODUCTION OF THE KEY AUDIT MATTERS (KAM) STANDARDS}

As noted above the unintended consequences in an audit environment can be described as the failure to match the reality of economics to the regulatory approaches adopted, which leads to results that are contrary to the objective of improving audit quality (Knechel \& Shefchik, 2014).

The prior corporate governance research highlights numerous instances in which legislation introduced for one purpose has unintended consequences, paradoxically aggravating the very problems that government sought to solve (see, for example, Unerman \& 0'Dwyer, 2004; Low et al., 2008; Riotto, 2008; Roberts, 2009; Vakkur, 2010; Bronson et al., 2011; Maroun, 2014).

\subsection{At the discretion of the auditor?}

As discussed above, it appears that the introduction of the KAM is aimed at reducing the 'information gap' (Knechel, Vanstraelen \& Zerni, 2015). However, what is of concern is the idea that it is at the auditor's discretion to decide which key audit matters should be included as part of the key audit matters based on the auditor's professional judgement and in view of the steps taken throughout the audit (Lessard, 2006; Bédard et al., 2014). It can then be assumed that the auditor's opinion will in all likelihood not change as a result of being compelled to disclose key matters, as ultimately the standard still seeks the auditor to express his/her opinion using the appropriate levels of professional scepticism and judgement (Lessard, 2006; Bédard et al., 2014). 
However, it could be asked whether the enhanced audit opinion disclosure and transparency could potentially push more audit opinions to the side of an unqualified opinion, simply by disclosing in more detail the issue, or potential issue that caused the auditor some concern (Lessard, 2006; Bédard et al., 2014). In a way, then, the enhanced disclosure may give the auditor more comfort in reaching an unqualified opinion, as the key issues and mechanisms used to address them are now transparent to the users.

\subsection{Boiler plate or value-add?}

Based on the above, the KAM would potentially serve purely as a mechanism to allow users greater insight into the issue and not into how the auditor firm reached its conclusion (Lessard, 2006; Bédard, Gonthier-Besacier \& Schatt, 2014).

The idea that auditors should disclose more detailed reports has spread widely since the 2008 financial crisis. The IAASB, the PCAOB and the European Commission are particularly in favour of the disclosure of key audit matters (or critical audit matters) by auditors. A few years ago, such a debate existed in France, where auditors are required to justify their opinions. This has been the case there since 2003.

France introduced a similar piece of legislation under the provision of commentaries called "Justification of Assessments" (JOA), which are required to form part of the audit reports of certain French companies (Bédard et al., 2014). A study was performed on this J0A by sampling 953 audit reports and studying the reaction of the French financial market at the announcement of the JOAs. Their findings revealed that the reaction of the market after the release of the JOAs were not different at all, suggesting minimal, if any, impact on investors.

Their study produced three significant findings:

1. The quality of the audit using earnings management as a proxy was not affected by the JOA.

2. The cost of the audit after including J0As was not significantly modified (the J0As were generally approximately two-page reports). As a result, the quality to cost ratio was not modified at all.

3. However, the efficiency lag (measured as the time between conclusion of the audit and issue of the audit report) had improved slightly. This is in contrast to concern expressed about this (Bédard et al., 2014).

Their research concluded that France was relatively non-reactive to the similar audit regulations after it was imposed.

Although not related directly to this topic, the implementation of the Reportable Irregularity (RI) is a further example of an instance where South Africa adopted a new standard based on international similarity that ended up having a very minor, if any, impact on the local audit reporting (Maroun, 2015b).

\subsection{Confidentiality and a possible greater risk?}

In considering section 4 further unintended consequences may also result.

Such key consequences, raised as questions, could be: 
1. What if the content of the KAM report contains information that is potentially confidential? For example, in the case of justifying going concern, what if key to the client's going concern is a strategic policy or decision or product that the client would not want disclosed in a public forum? While it is envisaged that the actual details would not be disclosed by the auditor, the auditor would have to substantiate how it addressed the going concern review and may give insight into its client's strategic plans. It is proposed that the market may react to this, specifically if speculation was that the entity is facing going concern difficulties.

2. Does the auditor's disclosure or expansion of its audit procedures carried out leave the audit firm vulnerable to external scrutiny and/or potential litigation? This may be both from its clients for divulging information that it deemed confidential or indeed from other market competitors and even the regulator itself.

This paper suggests, then, that requiring auditors to expand and justify their going concern work performed in order to justify their opinion may prove problematic. In particular, and as suggested by the IAASB, these key audit matters should be unique to each client and not boiler plate or templates.

The literature suggests that the audit opinion is to an extent not only a statement from the auditor but rather a form of joint statement from both client and auditor (Antle and Nalebuff, 1991). This literature suggests that the final opinion is the result of many discussions and negotiations between client and auditor, which may result in adjustments passed and opinions modified to a level acceptable to both client and the auditor. The authors describe the final audit report and audited financial statements as the 'final negotiated outcome'.

\subsection{Going concern in a South African context}

It is here that the author sees a potential pitfall and an unintended consequence with going concern being expanded on in the key audit matter. The International Standard on Auditing 570 (ISA 570) titled 'Going Concern' explains the assumption as follows; 'Under the going concern assumption, an entity is viewed as continuing in business for the foreseeable future'.

In a South African context, there is little evidence, if any, to suggest that the audit work around the going concern assumption is inadequate. In addition, ISA 570 has been updated over the last few years to address areas of concern, primarily in terms of what is a material uncertainty, and gives the auditor guidance in this regard (IAASB, 2014a).

With this in mind, is the key audit matter disclosure, in particular with regard to going concern in fact relevant in the South African context? This research suggests that the answer to this question is no, and that further in-depth research into this area should be undertaken before the systematic rollout of such reporting requirements in South Africa. This is further corroborated by Bédard et al. (2014), whose empirical evidence suggested that in France there was very little, if any, reaction by the market to entities whose first-time audit reports included a Justification of Assessment, also known as a key audit matter in a South African context.

With this in mind and as confirmed by Mr Montgomery, going concern is most likely to be a key audit matter, and there is a risk of firms using boiler plate (Bédard et al., 2014) or template type methodology to disclose these key audit matters (Carcello, Hermanson, \& Neal, 2002). Carcello et al. further suggest that it is this very type of boiler plate reporting in the US that detracted from the audit committees taking responsibility for the audits and their actions by producing long lists of to whom they discharged their obligations rather than how these obligations were discharged. 
Bédard et al. (2014) state, however, that prior research conducted in Europe may suggest otherwise. In their evaluation, (and corroborated by Church, Davis, \& Mccracken, 2008), the audit report is merely a symbolic gesture. In their opinion, investors permanently revise their expectations and do not wait for the auditor report. Hence it lacks significance.

The same may hold true for going concern review and may also apply to the auditor expressing his opinion on the entity's going concern. This research suggests that the users', and in particular the financial markets' (Bédard et al., 2014), reaction does not depend on the content of the audit report, even if it is more elaborate and more detailed. This may be exacerbated by the fact that the audit report including the key audit matters will be longer and runs a risk of being too standardised, too detailed and in fact too complex to be useful.

\subsection{Potential effects on the profession}

An additional concern is that the manner in which this new regulation is imposed and managed may have far-reaching consequences (as explained below) for the audit profession (Knechel \& Shefchik, 2014).

This legislation may result in auditors continually having to defend their judgements to answer for alleged failures in audit documentation that do not translate into broader audit failure, and to be potentially embarrassed in front of the public and clients. This is seen as a potential reputational risk.

This paper agrees with Knechel and Shefchik (2014), who suggest that this additional reporting is unlikely to improve the auditor's professional standing, attitude or satisfaction in providing professional services. This may lead to a negative environment that has the potential to damage the already fragile 'trust-relationship' between auditor and client (Knechel \& Shefchik, 2014).

A further concern is that this increased legislation could result in an exacerbation of the regulatory audit problems currently facing the profession (Knechel \& Shefchik, 2014), which could result in professional auditors choosing to leave the profession. This may then lead to a longerterm deterioration of the profession and a further reduction of the economic benefits and rewards of being involved in the profession (Knechel \& Shefchik, 2014). This paper serves to emphasise that these negative, but unintended, consequences may eventually arise (Knechel \& Shefchik, 2014).

\section{CONCLUSION}

This article provides an exploratory account of the introduction of the key audit matters standard (KAM) in a South African context. KAM and the reporting thereof is a fundamental shift in the nature of the audit report. As demonstrated by the literature, the effect on audit risk will need to be considered. It is suggested that in order for auditors to seek protection from not disclosing a key audit matter, audit reports may contain longer key audit matter reports in order to mitigate any potential risk, which the literature suggests may cause boiler plate type reporting.

Auditors will need to substantiate their findings further, particularly with regard to their clients' going concern. By highlighting procedures performed and potential assumptions made, indirectly the auditors may be disclosing what procedures were not done or not performed, which could raise questions by potential investors and users that ordinarily would not have been posed. A critical concern has been raised, which is that a case of increased transparency and legislation may in 
fact lead to an increase in 'questioning' and a potential decrease in the level of trust and confidence associated with the audit report, worsening an already fragile auditor-client relationship and adding an additional significant burden to the already arduous profession.

JSE-listed entities and their auditors will be the first to embark on this journey. This can be seen as a bold move by the regulator, a demonstration of sound belief in the principles associated with increased transparency with a view to greater investor confidence. On the other hand, any pitfalls and unintended consequences may be materially felt, and if this is the case, the effect may be harder-hitting as a result of the entities being JSE-listed than potentially would have been had the regulator considered a more conservative rollout, such as requiring a sample of non-listed entities first.

In reaching this conclusion, it must be noted that this study is not without limitations. It concentrates in an exploratory fashion only on the KAM introduction in South Africa to inform the ongoing debate. Future research needs to expand on this by examining the advantages and disadvantages of the introduction of equivalent legislative in other jurisdictions. In addition, this article has not carried out a detailed empirical analysis. Given the lack of formal literature on the KAM in South Africa, a qualitative study was best suited to offering initial insights. Subsequent work may expand on this in a positivist setting - for example, by creating a model to predict future costs, consequences and the negative impact on the auditing profession after the introduction of the KAM.

\section{LIST OF REFERENCES}

Ahrens, T., Becker, A., Burns, J., Chapman, C. S., Granlund, M., Habersam, M., Hansen, A., Khalifa, R., Malmi, T. \& Mennicken, A. (2008). The future of interpretive accounting research-a polyphonic debate. Critical Perspectives on Accounting, 19, pp. 840-866.

Antle, R. \& Nalebuff, B. (1991). Conservatism and auditor-client negotiations. Journal of Accounting Research, pp. 31-54.

Asare, S.K. (1992). The auditor's going-concern decision: Interaction of task variables and the sequential processing of evidence. Accounting Review, pp. 379-393.

Bédard, J., Gonthier-Besacier, N. \& Schatt, A. (2014). Cost and benefits of reporting key audit matters in the audit report: The French experience. Laval University, Canada.

Blay, A.D., Sneathen, L.D. \& Kizirian, T. (2007). The Effects Of Fraud And Going-Concern Risk on Auditors' Assessments of the Risk of Material Misstatement and Resulting Audit Procedures. International Journal of Auditing, 11, pp. 149-163.

Bowes, B., Lundy, G. \& Pennington, S. (2004). The story of our future: South Africa 2014. South AfricaThe Good News (Pty) Ltd, Hyde Park, Johannesburg.

Business Day. (2014). World bank paints a rosy picture of accounting and auditing in South Africa. Available: http://www.Bdlive.Co.Za/Opinion/Bdalpha/2014/05/23/World-Bank-Paints-RosyPicture-Of-Accounting-And-Auditing-In-South-Africa. (Accessed 27 May 2015).

Carcello, J.V. (2012). What Do Investors Want From The Standard Audit Report. The CPA Journal, (82), pp. 22-28.

Carcello, J.V., Hermanson, D.R. \& Neal, T.L. (2002). Disclosures In Audit Committee Charters and Reports. Accounting Horizons, 16, pp. 291-304. 
Carcello, J.V. \& Neal, T.L. (2000). Audit Committee Composition and Auditor Reporting. The Accounting Review, 75, pp. 453-467.

Chen, K.C. \& Church, B.K. (1996). Going Concern Opinions and The Market's Reaction To Bankruptcy Filings. Accounting Review, pp. 117-128.

Church, B.K., Davis, S.M. \& Mccracken, S.A. (2008). The Auditor's Reporting Model: A Literature Overview and Research Synthesis. Accounting Horizons, 22, pp. 69-90.

Cooke, T.E. (1992). The Impact Of Size, Stock Market Listing and Industry Type on Disclosure in The Annual Reports Of Japanese Listed Corporations. Accounting and Business Research, 22, pp. 229-237.

Cordos, G.S. \& Fulop, M.T. (2015). Understanding Audit Reporting Changes: Introduction Of Key Audit Matters. Journal of Accounting and Management Information Systems, 14, pp. 128-152.

Creswell, J.W. (2009). Research Design: Qualitative, Quantitative, and Mixed Methods Approaches. Sage Publications, Incorporated.

Defond, M.L., Raghunandan, K. \& Subramanyam, K. (2002). Do Non-Audit Service Fees Impair Auditor Independence? Evidence From Going Concern Audit Opinions. Journal of Accounting Research, pp. 1247-1274.

Demaki, G. (2011). Proliferation of Codes of Corporate Governance in Nigeria and Economic Development. Business and Management Review, 1, pp. 1-7.

Footprint Consultants (2011). Study of the Perception Of Statutory Auditors' Justification of assessments. Footprint Consultants.

Francis, J.R. (2004). What Do We Know About Audit Quality? The British Accounting Review, 36, pp. 345-368.

Gold, A., Gronewold, U. \& Pott, C. (2012). The ISA 700 Auditor's Report and The Audit Expectation GapDo Explanations Matter? International Journal Of Auditing, 16, pp. 286-307.

Grosu, M., Robu, I.B. \& Istrate, C. (2015). Exploratory Study Regarding The Impact Of IFRS On The Audit Opinion In The Case Of Romanian Listed Companies. Audit Financiar, 13.

Hayes, R., Wallage, P. \& Gortemaker, H. (2014). Principles Of Auditing: An Introduction to International Standards On Auditing, Pearson Higher $\varepsilon d$.

Hogan, C.E. \& Wilkins, M.S. (2008). Evidence On The Audit Risk Model: Do Auditors Increase Audit Fees in the Presence of Internal Control Deficiencies? Contemporary Accounting Research, 25(1), pp. 219242.

Humphrey, C., Kausar, A., Loft, A. \& Woods, M. (2011). Regulating Audit Beyond The Crisis: A Critical Discussion Of The Eu Green Paper. European Accounting Review, 20, pp. 431-457.

Humphrey, C., Samsonova, A. \& Siddiqui, J. (2013). Auditing, Regulation and The Persistence of the Expectations Gap. The Routledge Companion to Accounting, Reporting and Regulation, 163.

International Auditing and Assurance Standards Board (2014a). International Standards On Auditing 570: Going Concern.

International Auditing and Assurance Standards Board (2014b). International Standards On Auditing 700: Forming an Opinion and Reporting on Financial Statements.

International Auditing and Assurance Standards Board (2014c). International Standards On Auditing 705: Modifications to the Opinion in the Independant Auditors Report. 
International Auditing and Assurance Standards Board (2014d). International Standards On Auditing (Revised) 315: Identifying and Assessing the Risks Of Material Misstatement Through Understanding the Entity And its Enviroment.

International Auditing and Assurance Standards Board (2014e). International Standards On Auditing: 200 Overall Objectives of the Independent Auditor and the Conduct of an Audit in Accordance With International Standards on Auditing.

International Auditing and Assurance Standards Board (2014f). International Standards On Auditing: ISPC I Quality control for firms.

International Auditing and Assurance Standards Board (2015). International Standards On Auditing 701: Communicating Key Audit Matters in the Independent Auditors Report.

International Accounting Standards Board (2014). IAS 1: Presentation of Financial Statements.

Johnstone, K.M. (2000). Client-Acceptance Decisions: Simultaneous Effects of Client Business Risk, Audit Risk, Auditor Business Risk and Risk Adaptation. Auditing: A Journal of Practice \& Theory 19(1), pp. 1-25.

Knechel, W. \& Shefchik, L. (2014). Audit Quality. The Routledge Companion To Auditing.

Knechel, W., Vanstraelen, A. \& Zerni, M. (2015). Does The Identity Of Engagement Partners Matter? An Analysis Of Audit Partner Reporting Decisions. Contemporary Accounting Research, 32(4), pp.14431478.

Kretzschmar, L., Prinsloo, F., Prozesky, M., Rossouw, D., F Korien, S., Siebrits, J. \& Woermann, M. (2013). Ethics For Accountants and Auditors, $3^{\text {rd }}$ edition. Capoe Town: OUP.

Lessard, C. (2006). La “Gouvernance” De L'éducation Au Canada: Tendances et Significations. Education Et Sociétés, 18, pp. 181-201.

Mackenzie, B., Coetsee, D., Njikizana, T., Chamboko, R., Colyvas, B., \& Hanekom, B. (2013). Wiley IFRS 2013: Interpretation and Application of International Financial Reporting Standards. John Wiley \& Sons.

Maijoor, S. \& Vanstraelen, A. (2012). "Research Opportunities in Auditing in the EU," Revisited. Auditing: A Journal of Practice \& Theory, 31, pp. 115-126.

Maletta, M. J. (1993). An Examination Of Auditors' Decisions To Use Internal Auditors as Assistants: The Effect Of Inherent Risk. Contemporary Accounting Research, 9, pp. 508-525.

Maroun, W. (2012). Sox-A Comparison With the South African Status Quo. Journal Of Modern Accounting And Auditing, 8, pp. 357-364.

Maroun, W. (2015a). Peculiarities of The Fair Value Taxation Regime for Financial Instruments. South African Journal of Accounting Research, pp. 1-11.

Maroun, W. Reportable Irregularities And Audit Quality: Insights from South Africa. Accounting Forum, (2015b). Elsevier, pp. 19-33.

Maroun, W. \& Atkins, J. (2014). Section 450 of The Auditing Profession Act: Blowing the Whistle for Audit Quality? The British Accounting Review, 46, pp. 248-263.

Maroun, W. \& Gowar, C. (2013). South African Auditors Blowing The Whistle Without Protection: A Challenge For Trust And Legitimacy. International Journal of Auditing, 17, pp. 177-189.

Melis, G. \& Melis, A. (2004). Corporate Governance in Italy. Was It A Financial Reporting Failure? Corporate Governance: An International Review, 8(4), pp. 347-355. 
Melis, A. (2005). Corporate Governance Failures: To what extent is Parmalat a particularly Italian Case?. Corporate Governance: An International Review, 13(4), pp. 478-488.

Nkonki. (2015). Technical Update. Available: http://www.Nkonki.com/Insights/TechnicalUpdate/63-The-New-Auditor-S-Report. (Accessed 8 September 2015).

PCAOB. (2007). Report On The Second-Year Implementation Of Auditing Standard No. 2: An Audit of Internal Control Over Financial Reporting Performed In Conjunction With An Audit Of Financial Statements. Washington, DC. Available: http://Pcaobus.Org/Inspections/Documents/2006_0321_Release_104-2006-078.Pdf (Accessed l September 2015).

Parker, L., Guthrie, J., Milne, M. \& Humphrey, C. (2008). Auditing Research: A Review Across the Disciplinary Divide. Accounting, Auditing \& Accountability Journal, 21, pp. 170-203.

Porter, B. \& Gowthorpe, C. (2004). Audit Expectation-Performance Gap In the United Kingdom in 1999 and Comparison with the Gap in New Zealand in 1989 and in 1999, Institute of Chartered Accountants of Scotland.

Power, M. (1994). The Audit Explosion, Demos.

Puttick, G., Van Esch, S., Van Esch, S. D. \& Kana, S. (2008). The Principles and Practice of Auditing. Juta and Company Ltd.

Schiefer, K. (2014). Time Will Tell. Verbum, 6, pp. 19.

Schilder, A. (2011). Audit Quality An IAASB Perspective. International Auditing and Assurance Standards Board.

Segal, M. \& Maroun, W. (2014). The Introduction Of a Gambling Tax in South Africa-What Are The Odds on the Implementation Thereof? Journal of Economic and Financial Sciences, 7, pp. 361-374.

Simpson, J.A. \& Weiner, દ.S. (1989). The Oxford English Dictionary. Clarendon Press Oxford.

Stiglingh, M. (ed.) (2011). Silke: South African Income Tax 2011. LexisNexis: South Africa.

Unerman, J. \& O'Dwyer, B. (2004). Enron, Worldcom, Andersen et al.: A Challenge To Modernity. Critical Perspectives on Accounting, 15, pp. 971-993.

Vakkur, N.V., McAfee, R.P. \& Kipperman, F. (2010). The Unintended Effects of the Sarbanes-0xley Act Of 2002. Research In Accounting Regulation, 22, pp. 18-28.

World Economic Forum (2014). Available: http: //www.Sablog.Kpmg.Co.Za/2014/09/Wef-Voted-

South-Africa-1-Auditing-Reporting-Standards. (Accessed 16 April 2016). 